\title{
Influence of culture media in viability test of conidia of entomopathogenic fungi
}

\author{
Influência de meios de cultura em teste de viabilidade de fungos entomopatogênicos
}

\author{
Edimara Aparecida Francisco $^{1}$ Dinalva Alves Mochì $^{2}$ Antônia do Carmo Barcelos Correia ${ }^{3}$ \\ Antonio Carlos Monteiro ${ }^{4}$
}

- NOTE - lecanii, cinco de Beauveria bassiana e quatro de Paecilomyces fumosoroseus. Os testes foram realizados em lâminas de microscopia contendo um dos seguintes meios de cultura: Ágarágua (AA), Meio Mínimo (MM), Batata, dextrose e ágar (BDA), Batata, dextrose, ágar e $1 \%$ de extrato de levedura (BDAL), Sabouraud, dextrose, ágar e extrato de levedura (SDAL) e Meio Completo (MC). Delimitaram-se três áreas por lâmina e em cada uma aplicou-se $0,05 \mathrm{~mL}$ de uma suspensão com concentração de 5,5 $\times 10^{5}$ conídios $\mathrm{mL}^{-1}$. Para cada isolado foi realizado um bioensaio, com seis tratamentos e cinco repetições. Avaliou-se a germinação 15 horas após incubação, a $26 \pm 0,5^{\circ} \mathrm{C}$. Os meios de cultura influíram na capacidade de germinação das três espécies estudadas, ocorrendo variações inter e intraespecíficas. Verificou-se que os meios Completo e BDA proporcionaram as maiores porcentagens de germinação dos isolados de L. lecanii, sendo que e as menores foram obtidas nos meios SDAL e AA. Os meios ricos em nutrientes (BDA, BDAL e Completo) favoreceram a germinação dos isolados de B. bassiana, o que não ocorreu com os meios pobres (AA $e$ $M M)$. Nos meios Completo e BDA foram obtidas as maiores porcentagens de germinação dos isolados de $\boldsymbol{P}$. fumosoroseus. As menores percentagens, por sua vez, foram obtidas no meio SDAL. Entretanto, alguns isolados apresentaram alta germinação em meios pobres em nutrientes (AA e MM).

Palavras-chave: Beauveria bassiana, Lecanicillium lecanii, Paecilomyces fumosoroseus, controle microbiano, germinação.

Bioinsecticides based on entomopathogenic fungi are currently commercialized, mainly using the de cultura utilizados em teste de viabilidade afetam germinação de conídios de cinco isolados de Lecanicillium

\footnotetext{
${ }^{1}$ Microbiologia Agropecuária, Faculdade de Ciências Agrárias e Veterinárias (FCAV), Universidade Estadual Paulista (Unesp). Email: edimarafrancisco@bol.com.br.

${ }^{2}$ Programa de Pós-graduação em Microbiologia Agropecuária, FCAV/Unesp. E-mail:dmochi@fcav.unesp.br.

${ }^{3}$ Departamento de Fitossanidade, FCAV/Unesp.

${ }^{4}$ Departamento de Produção Vegetal, FCAV/Unesp. Via de Acesso Prof. Paulo Donato Castellane, s/n, 14844-900, Jaboticabal, SP, Brasil. E-mail: montecar@fcav.unesp.br. Autor para correspondência.
} 
species Beauveria bassiana (Bals.) Vuillemin, Metarhizium anisopliae (Metsch.) Sorokin, Lecanicillium lecanii Zare \& Gams, and Paecilomyces fumosoroseus (Wize) Brown and Smith (LACEY et al., 2001). The viability of the fungus should be evaluated since it is an important component of the quality of the product (ALVES \& PEREIRA, 1998). The virulence of these fungi has been correlated with the velocity of germination (HASSAN \& CHARNLEY, 1989). In this respect, viability tests permit the evaluation of the germination capacity of conidia from its production to is field application.

Viability tests can be performed by spreading $10 \mu \mathrm{L}$ of a aqueous conidial suspension on Petri dishes containing a thin layer of potato-dextrose agar (PDA) medium (ALVES et al., 1998). Some researchers perform the test by placing the culture medium on microscope slides and adding drops of the conidial suspension (EKESI et al., 2001). The number of germinated conidia can be determined after 16 hours depending on the fungus and temperature (ALVES \& PEREIRA, 1998).

Various culture media have been adopted to test conidial viability such as potato-dextrose-yeast extract agar, agar-water, Sabouraud-dextrose agar, and Sabouraud-maltose-yeast agar.

Certain treatments or the addition of chemical that are not required to support hyphal growth can activate germination (MOORE-LANDECKER, 1972). Physical or chemical environmental factors such as temperature, light, moisture, $\mathrm{pH}$, substratum composition (MOORE-LANDECKER, 1972), $\mathrm{O}_{2}$ and $\mathrm{CO}_{2}$ (CARLILE et al., 2001), or any combination of these can activate spore germination. Therefore, composition of culture medium is an important factor to be considered.

The nutritional requirements for germination of entomopathogenic fungi are generally not complex (SMITH \& GRULA, 1981), but various fungal species require different chemical, physical and nutritional conditions for optimal germination (CARLILE et al., 2001). In this context, the objective of the present study was to investigate whether the culture medium used in viability test influences the germination of isolates of three entomopathogenic fungal species.

The following species were studied: Beauveria bassiana (isolates JAB 6, JAB 7, AM 9, IBCB 7, and IBCB 66), Paecilomyces fumosoroseus (isolates JAB 12, IBCB 137, IBCB 201, and IBCB 148), and Lecanicillium lecanii (isolates ARSEF 6430, ARSEF 6431, ARSEF 6432, JAB 2, and JAB 45). These isolates have been deposited in the collections of Microbiology Laboratory and Laboratory of
Entomopathogens, Plant Production and Phytosanity Departments respectively, Faculty of Agrarian and Veterinary Sciences, Sao Paulo State University.

The fungi were cultured on potatodextrose-agar medium (PDA) for 7 days at $26 \pm 0.5^{\circ} \mathrm{C}$ under 14-hour photoperiod. A conidial suspension of each isolate was prepared adding $10 \mathrm{ml}$ of an aqueous $0.1 \%(\mathrm{v} / \mathrm{v})$ Tween $80^{\circledast}$ solution to each funguscontaining plate. The surface of each colony was gently swept, the suspension formed was filtered and shaken in an electrical tube shaker. Conidial concentrations were estimated in a Neubauer chamber and adjusted to $5.5 \times 10^{5}$ conidia $\mathrm{ml}^{-1}$.

One bioassay was performed for each isolate, for a total of 14 assays. The following culture media (treatments) were used in each bioassay: $1 \%$ agar-water (AW), minimal medium (MM) (PONTECORVO et al., 1953), PDA, potato-dextrose-1\% yeast extract agar (PDAY), Sabouraud-dextrose-1\% yeast extract agar (SDAY) (ALVES et al., 1998), and complete medium (CM) (PONTECORVO et al., 1953, modified by AZEVEDO \& COSTA, 1973).

The tests were performed using microscope slides disinfected with $70 \%$ alcohol. After the demarcation of three areas on the bottom surface, the slides were placed on Petri dishes, with a high relative humidity being maintained by two cotton pads moistened with distilled water. Two matches were placed in the horizontal position under each slide to prevent it from touching to touch the plate's bottom. Each slide's surface was covered with $4 \mathrm{ml}$ of culture medium and one drop (approximately $0.05 \mathrm{ml}$ ) of the conidial suspension was placed in each area. After 15 hours of incubation at $26 \pm 0.5^{\circ} \mathrm{C}$, the germination process was stopped by dribbling one drop of dye ( $1 \mathrm{ml}$ of a stock solution consisting of $1 \mathrm{~g}$ methylene blue in $20 \mathrm{ml}$ lactic acid was added to $29 \mathrm{ml}$ lactic acid) on each area. One-hundred-and-fifty conidia, both germinated and non-germinated ones, were observed per area. Five slides (replications) were made for each treatment so that a total of 2,250 conidia per treatment could be observed and the percentage of viable conidia could be calculated.

A fully randomized design was adopted in all bioassays, including six treatments and five replications. The analyses were performed by the $\mathrm{F}$ test and means were compared by the Tukey test at a $5 \%$ probability error, using the ESTAT program (FCAV/ Unesp, Exact Sciences Department).

Conidial viability analysis of $\boldsymbol{L}$. lecanii isolates set showed that CM and PDA provided the highest germination percentages, while the lowest percentages were obtained with SDAY and AW medium 
(Table 1). However, analysis of each isolate showed that the germination percentages obtained for $\mathrm{CM}$ and PDA were statistically equal to those observed for some of the other media.

The highest germination of $\boldsymbol{B}$. bassiana conidia was provided by PDA, PDAY, SDAY, and CM (Table 1). For isolates of this fungus, nutrient-rich media favoured germination, while MM and AW medium, which possesses a lower nutritional value, promoted lower germination. The difference between media contributing or not to germination was more evident for B. bassiana than for L. lecanii. A markedly lower percentage of germination was observed for AM 9 isolate than for others.

B. bassiana requires a utilizable carbon sources to promote germination and a nitrogen source is needed for continued hyphal growth (SMITH \& GRULA, 1981). Nevertheless, the authors suggested that conidia possess ample endogenous nitrogen reserves for synthesis of protein required for the germination process, since germination and some growth can occur in the absence of an exogenous nitrogen source. Nutrient-rich media contain various carbon and nitrogen sources, a factor that might have been decisive in the observation of higher germination percentages.

The highest percentages for conidial germination of $\boldsymbol{P}$. fumosoroseus isolates were obtained on CM and PDA and the lowest percentages on SDAY (Table 1). Furthermore, nutrient-poor (MM) or -free medium (AW) promoted high germination of IBCB 201 and IBCB 148 isolates, a fact also observed for some $\boldsymbol{L}$. lecanii isolates. This observation suggests that these isolates are endowed with a good nutritional reserve. Some spores require an exogenous source of carbon or nitrogen for germination, while others do not require exogenous sources of nutrients but they utilize their reserve material such as carbohydrates, lipids or proteins (MOORE-LANDECKER, 1972). Genetic differences between isolates probably play a decisive role in this finding.

The results obtained with CM and PDA are probably due to their rich composition. CM includes an adequate sugar (glucose) and various macro- and

Table 1 - Conidial germination (\%) of Lecanicillium lecanii, Beauveria bassiana and Paecilomyces fumosoroseus isolates in some culture media at $26 \pm 0.5^{\circ} \mathrm{C}^{1,2}$.

\begin{tabular}{|c|c|c|c|c|c|c|c|}
\hline \multirow[t]{2}{*}{ Fungus } & \multicolumn{6}{|c|}{ Culture Media } & \multirow[t]{2}{*}{ C.V. ${ }^{9}$} \\
\hline & $\mathrm{AW}^{3}$ & $\mathrm{MM}^{4}$ & $\mathrm{PDA}^{5}$ & $\mathrm{PDAY}^{6}$ & $\mathrm{SDAY}^{7}$ & $\mathrm{CM}^{8}$ & \\
\hline \multicolumn{8}{|c|}{ Lecanicillium lecanii } \\
\hline JAB 45 & $92.1 \mathrm{~b}$ & $67.3 \mathrm{c}$ & $96.7 \mathrm{a}$ & $96.9 \mathrm{a}$ & $97.9 \mathrm{a}$ & $96.0 \mathrm{ab}$ & 3.35 \\
\hline JAB 2 & $93.3 \mathrm{c}$ & $97.1 \mathrm{ab}$ & $99.2 \mathrm{a}$ & $99.0 \mathrm{a}$ & $96.6 \mathrm{bc}$ & $98.6 \mathrm{a}$ & 3.11 \\
\hline ARSEF 6430 & $99.6 \mathrm{a}$ & $99.6 \mathrm{a}$ & $99.4 \mathrm{a}$ & $97.8 \mathrm{~b}$ & $96.8 \mathrm{~b}$ & $99.4 \mathrm{a}$ & 2.09 \\
\hline ARSEF 6431 & $99.5 \mathrm{ab}$ & $99.7 \mathrm{a}$ & $99.1 \mathrm{~b}$ & $96.3 \mathrm{~d}$ & $98.2 \mathrm{c}$ & $99.5 \mathrm{ab}$ & 1.40 \\
\hline ARSEF 6432 & $97.7 \mathrm{~b}$ & $99.1 \mathrm{ab}$ & $99.4 \mathrm{a}$ & $99.1 \mathrm{ab}$ & $97.9 \mathrm{ab}$ & $98.5 \mathrm{ab}$ & 2.58 \\
\hline \multicolumn{8}{|c|}{ Beauveria bassiana } \\
\hline JAB 6 & $83.2 \mathrm{c}$ & $89.3 \mathrm{~b}$ & $98.2 \mathrm{a}$ & $98.0 \mathrm{a}$ & $97.7 \mathrm{a}$ & $97.5 \mathrm{a}$ & 2.56 \\
\hline JAB 7 & $98.3 \mathrm{bc}$ & $91.0 \mathrm{c}$ & $98.8 \mathrm{a}$ & $97.3 \mathrm{a}$ & $95.5 \mathrm{abc}$ & $95.7 \mathrm{ab}$ & 3.92 \\
\hline IBCB 7 & $87.5 \mathrm{c}$ & $90.3 \mathrm{bc}$ & $96.6 \mathrm{a}$ & $94.4 \mathrm{ab}$ & $97.3 \mathrm{a}$ & $97.6 \mathrm{a}$ & 4.45 \\
\hline AM 9 & $41.5 \mathrm{c}$ & $42.8 \mathrm{c}$ & $74.2 \mathrm{ab}$ & $74.0 \mathrm{ab}$ & $78.7 \mathrm{a}$ & $69.5 \mathrm{~b}$ & 5.66 \\
\hline IBCB 66 & $76.4 \mathrm{~b}$ & $74.3 \mathrm{~b}$ & $94.9 \mathrm{a}$ & $94.3 \mathrm{a}$ & $95.4 \mathrm{a}$ & $94.5 \mathrm{a}$ & 4.12 \\
\hline \multicolumn{8}{|c|}{ Paecilomyces fumosoroseus } \\
\hline JAB 12 & $92.1 \mathrm{c}$ & $93.3 \mathrm{~b}$ & $98.6 \mathrm{a}$ & $98.8 \mathrm{a}$ & $97.9 \mathrm{a}$ & $96.0 \mathrm{ab}$ & 3.35 \\
\hline IBCB 137 & $93.3 \mathrm{c}$ & $97.1 \mathrm{ab}$ & $99.2 \mathrm{a}$ & $99.0 \mathrm{a}$ & $96.6 \mathrm{bc}$ & $98.6 \mathrm{a}$ & 3.11 \\
\hline IBCB 201 & $99.6 \mathrm{a}$ & $99.6 \mathrm{a}$ & $99.4 \mathrm{a}$ & $97.8 \mathrm{~b}$ & $96.8 \mathrm{~b}$ & $99.4 \mathrm{a}$ & 2.09 \\
\hline IBCB 148 & $99.5 \mathrm{ab}$ & $99.7 \mathrm{a}$ & $99.1 \mathrm{~b}$ & $96.3 \mathrm{~d}$ & $98.2 \mathrm{c}$ & $99.5 \mathrm{ab}$ & 1.40 \\
\hline
\end{tabular}

${ }^{1}$ Means showed in original value, but statistical analysis data were transformed in $\operatorname{arc} \sin (\mathrm{x} / 100)^{1 / 2}$

${ }^{2}$ Means followed by same letter on line are not significantly different at $5 \%$ of probability by Tukey test.

${ }^{3}$ Agar- water.

${ }^{4}$ Minimal medium.

${ }^{5}$ Potato, dextrose and agar.

${ }^{6}$ Potato, dextrose, agar and $1 \%$ yeast extract.

${ }^{7}$ Sabouraud, dextrose, agar and $1 \%$ yeast extract.

${ }^{8}$ Complete medium.

${ }^{9}$ Coeficient of variation (\%).

Ciência Rural, v.36, n.4, jul-ago, 2006. 
micronutrient sources (inorganic salts, peptone, casein hydrolysate and yeast extract) required by the fungi, in addition to vitamins. PDA is a complex medium that includes dextrose and soluble starch and proteins. According to MOORE-LANDECKER (1972), under laboratory conditions, spore germination may be triggered by the addition of a diverse range of chemical agents including inorganic ions, carbohydrates, amino acids, lipids and vitamins, among others.

The germinative tubes of some isolates were much larger on any media than on others, indicating their faster germination. Although not measured specifically, a higher germination velocity was observed for the nutrient-rich media (PDA, PDAY, SDAY and CM), suggesting that the composition of culture medium can influence the germination velocity of conidium. Furthermore, due their rich composition, probably these media favour the growth of germinative tube.

Consistent information about the effect of the composition of the culture medium on conidial germination of entomopathogenic fungi is scarce on literature. The results of the present study showed that nutrient-rich media promote higher conidial germination; however, this was not a general rule, as observed for SDAY medium. For some isolates, nutrientpoor (MM) or -free medium (AW) can promote high germination. These differences are probably due to the genetic variability between isolates. Therefore, we conclude that culture media have an influence on the germination capacity of $\boldsymbol{B}$. bassiana, $\boldsymbol{L}$. lecanii and $\boldsymbol{P}$. fumosoroseus. This influence differs among species, and varies within the same species from one isolate to another. Thus, this fact should be considered when performing viability tests, choosing the most adequate medium for the fungus under study.

\section{REFERENCES}

ALVES, S.B. et al. Técnicas de laboratório. In: ALVES, S.B. Controle microbiano de insetos. 2.ed. Piracicaba: FEALQ, 1998. Cap.20, p.637-712.

ALVES, S.B.; PEREIRA, R.M. Produção de fungos entomopatogênicos. In: ALVES, S.B. Controle microbiano de insetos. 2.ed. Piracicaba: FEALQ, 1998. Cap. 27, p.845869 .

AZEVEDO, J.L.; COSTA, S.O.P. Exercícios práticos de genética. São Paulo: Nacional e Edusp, 1973. 288p.

CARLILE, M.J. et al. Spore dormancy and dispersal. In: CARLILE, M.J. et al. The fungi. 2.ed. San Diego: Academic, 2001. Cap.4, p.185-243.

EKESI, S. et al. Laboratory evaluation of the entomopathogenic fungus, Metarhizium anisopliae for the control the groundnut bruchid, Caryedon serratus on groundnut. Journal of Stored Products Research, Oxford, v.37, n.4, p.313-321, 2001.

HASSAN, A.E.M.; CHARNLEY, A.K. Ultrastructural study of the penetration by Metarhizium anisopliae through dimilinaffected cuticle of Manduca sexta. Journal of Invertebrate Pathology, Orlando, v.54, n.1, p.117-124, 1989.

LACEY, L.A. et al. Insect pathogens as biological control agents do they have a future? Biological Control, San Diego, v.21, n.3, p.230-248, 2001.

MOORE-LANDECKER, E. Fundamentals of the fungi. 4.ed. New Jersey: Prentice Hall, 1972. 574p.

PONTECORVO, G. et al. The genetics of Aspergillus nidulans. Advances in Genetics, San Diego, v.5, p.141-238, 1953.

SMITH, R.J.; GRULA, E.A. Nutritional requeriments for conidial germination and hyphal growth of Beauveria bassiana. Journal of Invertebrate Pathology, Orlando, v.37, n.3, p.222-230, 1981 . 